\title{
Pengaruh Pengawasan, Budaya Organisasi dan Remunerasi Terhadap Motivasi Kerja Pegawai
}

\author{
Lolasari Novelly Hutabarat \\ Program Studi Magister Manajemen, Universitas Muhammadiyah Sumatera Utara Medan, Indonesia \\ Jl. Denai No. 217, Tegal Sari Mandala II, Medan Denai, Kota Medan, Sumatera Utara 20371 \\ Email: sarilola71@gmail.com
}

\begin{abstract}
Abstrak.Tujuan penelitian ini adalah untuk menguji dan mengetahui pengaruh pengawasan, budaya organisasi, dan Remunerasi terhadap motivasi kerja pegawai pada satuan kerja Biro SDM Polda Sumatera utara baik secara parsial maupun simultan. Populasi dalam penelitian ini adalah seluruh pegawai pada satuan kerja Biro SDM Polda Sumatera utara yang berjumlah 86 orang dan menjadi sampel dalam penelitian ini Pegawai Negeri Sipil berjumlah 40 orang (purposive sampling). Data dikumpulkan dengan wawancara, daftar pertanyaan dan studi dokumentasi dan variabel-variabel yang diteliti menggunakan skala likert. Daftar pertanyaan terlebih dahulu diuji dengan menggunakan pengujian validitas dan reliabilitas, pengolahan data menggunakan perangkat lunak SPSS versi 20.0 dan dianalisis dengan regresi linear berganda. Hasil yang ditemukan dalam pengujian hipotesis penelitian ini adalah: Secara simultan variabel pengawasan, budaya organisasi dan remunerasi berpengaruh positif dan signifikan terhadap motivasi kerja pegawai pada satuan kerja Biro SDM Polda Sumatera Utara, secara parsial pengawasan berpengaruh negatif dan tidak signifikan terhadap motivasi kerja pegawai pada satuan kerja Biro Sumber Daya Manusia Polda Sumut, budaya organisasi berpengaruh signifikan dan positif terhadap motivasi kerja pegawai pada satuan kerja Biro Sumber Daya Manusia Polda Sumut dan remunerasi berpengaruh signifikan dan positif terhadap motivasi kerja pegawai pada satuan kerja Biro Sumber Daya Manusia Polda Sumut.
\end{abstract}

Kata kunci: Pengawasan, Budaya Organisasi, Remunerasi, Motivasi Kerja

\begin{abstract}
The purpose of this study was to examine and determine the effect of supervision, organizational culture, and remuneration on employee work motivation in the North Sumatra Regional Police Human Resources Bureau work unit both partially and simultaneously. The population in this study were all employees in the work unit of the North Sumatra Regional Police Human Resources Bureau which amounted to 86 people and became the sample in this study were 40 Civil Servants (Purposive Sampling). Data is collected by interviews, questionnaires and documentation studies and variables studied using a Likert scale. The questionnaire was first tested using validity and reliability testing, data processing using SPSS version 20.0 software, and analyzed by multiple linear regression. The results found in the hypothesis testing of this study are: Simultaneously the supervision variables, organizational culture and remuneration have a positive and significant effect on employee work motivation in the North Sumat ra Regional Police HR Bureau work unit, supervision partially has a negative and insignificant effect on employee motivation at work the work of the North Sumatra Regional Police Human Resources Bureau, organizational culture has a significant and positive effect on employee motivation in the work unit of the North Sumatra Regional Police Human Resources Bureau and remuneration has a significant and positive effect on employee motivation at the North Sumatra Regional Police Human Resources.
\end{abstract}

Keywords : Supervision, Organizational Culture, Remuneration, Work Motivation

\section{PENDAHULUAN}

Polda Sumatera Utara merupakan satu kesatuan yang terdiri dari beberapa Satuan kerja/ Satuan wilayah yang mempunyai karakteristik wilayah dan masyarakat yang berbeda, sehingga 
dapat menjadikan berbagai macam permasalahan dan persoalan yang kemungkinan akan terus berkembang sehingga akan menimbulkan kerawanan-kerawanan diberbagai bidang. Dengan demikian menuntut semua pihak, baik masyarakat maupun pemerintah daerah turut bertanggung jawab untuk mengatasinya dan apabila tidak ditangani sesuai dengan sistem yang baik maka pemerintah tidak dapat lagi menjalani kewajibannya, hal tersebut berpengaruh terhadap institusi Polri dikarenakan Polri adalah salah satu fungsi pemerintah di bidang keamanan yang bertanggung jawab atas keamanan individu dan keamanan umum sesuai UU No. 2 Tahun 2002 yang menyebutkan bahwa "tugas pokok Polri adalah memelihara ketertiban masyarakat, penegak hukum dan pelindung, pengayom serta sebagai pelayan masyarakat".

Polri pada saat ini dituntut agar meningkatkan profesionalisme dalam melaksanakan tugas, baik dibidang operasional maupun dibidang pembinaan, dimana satuan kerja Biro Sumber Daya Manusia Polda Sumut sebagai pembina fungsi manajemen pegawai yang meliputi penyediaan, penggunaan, perawatan, pemisahan dan penyaluran, diklat juga termasuk psikologi pegawai serta upaya peningkatan kesejahteraan pegawai di lingkungan Polda Sumut. Satuan kerja Biro Sumber Daya Manusia Polda Sumut terus berupaya melakukan pembenahan di bidang pegawai guna menghasilkan dan menciptakan sosok pegawai yang profesional dan dicintai masyarakat. Untuk menciptakan hal tersebut dengan melakukan pengawasan, penguatan budaya organisasi dan pemberian remunerasi untuk meningkatkan motivasi kerja pegawai melalui manajemen pembinaan pegawai, terlebih lagi dalam rangka pemberdayaan pegawai itu sendiri.

Kadarisman, (2013) mengatakan sebagai seorang individu pegawai juga mempunyai sesuatu yang utama mengenai perilaku, sikap, tabiat dan kebiasaan-kebiasaan yang tumbuh dan berkembang yang dibentuk oleh kondisi lingkungan dan pengalaman ditempat kerjanya". Tujuan organisasi akan Sulit dicapai bila para pegawai tidak mau menggali potensi yang ada dalam dirinya untuk bekerja semaksimal mungkin. Menurut (Utomo, 2008) motivasi kerja merupakan petunjuk atau dorongan untuk mengarahkan pegawai. Motivasi merupakan salah satu hal yang mempengaruhi prilaku manusia. Motivasi disebut juga sebagai pendorong, keinginan, pendukung atau kebutuhankebutuhan yang dapat membuat seseorang bersemangat dan termotivasi untuk mengurangi serta memenuhi dorongan diri sendiri, sehingga dapat bertindak dan berbuat menurut cara-cara tertentu yang akan membawa ke arah yang optimal (Jufrizen, 2017).

Pada satuan kerja Biro Sumber Daya Manusia Polda Sumut dengan motivasi kerja pegawai yang rendah akan membuat organisasi sulit untuk meningkatkan daya saing dengan organisasi lain, motivasi kerja yang rendah juga akan membuat kerugian bagi organisasi karena motivasi kerja yang rendah dapat mengakibatkan pegawai tidak mau memberikan yang terbaik bagi organisasi dimana pegawai tidak akan bekerja sepenuh hati, selain itu pegawai juga tidak akan mampu menyelesaikan pekerjaannya dengan baik ditandai dengan kurangnya tanggung jawab pegawai menyelesaikan pekerjaan sesuai dengan waktu yang ditentukan dan ketidakhadiran mengikuti Apel serta terlambat datang ke kantor. Sarwoto, (2011) menyatakan bahwa pengawasan adalah kegiatan yang diusahakan manajer agar pekerjaan terlaksana sesuai dengan rencana yang ditetapkan dan hasil yang dikehendaki. Dimana secara eksplisit subjek yang melaksanakan pengawasan atau memiliki fungsi pengawasan adalah manajer sebagai standar atau tolak ukur dari rencana yang ditetapkan atau hasil yang dikehendaki. Handoko, (2016) mengemukakan bahwa pengawasan adalah "suatu usaha sistematika yang menetapkan standar pelaksanaan dengan tujuan perencanaan, merancang sistem umpan balik". Membandingkan kegiatan nyata dengan standar yang telah ditetapkan sebelumnya, menentukan dan mengukur penyimpangan serta mengambil tindakan pemeriksaan yang diperlukan untuk menjamin semuanya. 
Budaya organisasi diungkapkan melalui sikap, sistem keyakinan, impian, perilaku, nilai-nilai, tata cara dari organisasi dan paling utama melalui tindakan serta kinerja pegawai dan manajemen. Menurut (Riani, 2011) budaya organisasi juga merupakan "keyakinan dan kebiasaan-kebiasaan dalam suatu organisasi yang saling berinteraksi dengan struktur formalnya untuk menciptakan norma-norma perilaku”. Penerapan budaya organisasi pada satuan kerja Biro Sumber Daya Manusia Poda Sumut belum kuat, dilihat dari kurangnya kebersamaan dalam melaksanakan pekerjaan dan kurangnya kepercayaan pimpinan terhadap pegawai karena masih ada pegawai yang tidak sungguh-sungguh menyelesaikan tugasnya. Beberapa hasil penelitian menunjukkan bahwa budaya organisasi berpengaruh terhadap kepuasan kerja, komitmen organisasi, kinerja dan motivasi kerja pegawai (Jufrizen, Lumbanraja, Salim, \& Gultom, 2017); (Jufrizen, 2017); (Jufrizen, Gultom, Sitorus, Sari, \& Nasution, 2018); (Muis, Jufrizen, \& Fahmi, 2018); (Gultom, 2014); (Ainanur \& Tirtayasa, 2018) dan (Elizar \& Tanjung, 2018).

Menurut Maryesa, Sukmawati, \& Wijayanto, (2016) remunerasi merupakan "bagian yang tidak terpisahkan dari kebijakan reformasi birokrasi. Dilatarbelakangi oleh kesadaran sekaligus komitmen pemerintah untuk mewujudkan clean and good governance”. Remunerasi yang merupakan imbalan kerja di luar gaji yang dikaitkan dengan sistem penilaian kinerja diharapkan akan dapat meningkatkan motivasi kerja pegawai sehingga biaya yang dikeluarkan yaitu berupa sejumlah uang tidak sia-sia, remunerasi saat ini telah diterima Pegawai Negeri diberbagai instansi termasuk pegawai di satuan kerja Biro Sumber Daya Manusia Polda Sumut, namun demikian belum terlihat sampai sekarang ini motivasi yang tinggi dalam bekerja pada pegawai pada satuan kerja Biro Sumber Daya Manusia Polda Sumut. Dengan turunnya Peraturan Presiden Republik Indonesia nomor 89 tahun 2015 tentang "remunerasi/tunjangan kinerja Pegawai di lingkungan Kepolisian Negara Republik Indonesia" yang kemudian direalisasikan dengan Peraturan Kepala Kepolisian Negara Republik Indonesia Nomor 13 Tahun 2015 tentang "tatacara pemberian remunerasi/tunjangan Kinerja bagi Pegawai di lingkungan Kepolisian Negara Republik Indonesia”.

\section{LANDASAN TEORI \\ Motivasi Kerja}

Motivasi berasal dari kata motove atau dengan bahasa latinnya yaitu movere, yang berarti "mengarahkan". Menurut Nawawi, (2011) kata motivasi (motivation) berasal dari kata dasar motive yang berarti dorongan sebab atau alasan seseorang melakukan sesuatu. Dengan demikian motivasi merupakan kondisi yang mendorong atau membuat seseorang melaksanakan kegiatan secara langsung dengan sadar. Menurut (Martoyo, 2000) bahwa manusia dalam aktivitas kebiasaannya melakukan sesuatu asalkan dapat menghasilkan sesuatu yang menganggap dirinya memiliki suatu nilai yang sangat berharga, yang tujuannya untuk melangsungkan kehidupannya, rasa tentram, rasa aman dan sebagainya. Buhler, (2004) menyatakan, motivasi pada dasarnya adalah proses yang menentukan seberapa banyak usaha yang akan diberikan untuk melaksanakan pekerjaan. Motivasi atau dorongan untuk bekerja ini sangat menentukan bagi tercapainya sesuatu tujuan, maka organisasi harus dapat menumbuhkan motivasi kerja setinggi-tingginya bagi para karyawan dalam perusahaan.

Menurut Kadarisman, (2013) motivasi bukanlah pekerjaan sambilan dan bukanlah sesuatu tambahan setelah organisasi didirikan dan dioperasikan, namun motivasi diawali dengan adanya kebutuhan yang tidak terpenuhi dan menyebabkan pegawai berusaha memenuhi kebutuhan dengan memasuki suatu organisasi dan dari sanalah muncul perilaku karyawan yang diarahkan untuk pencapaian suatu tujuan. Hasibuan, (2014) menyatakan bahwa motivasi kerja adalah daya kegairahan kerja yang diberikan kepada seseorang supaya mereka mau 
bekerja sama, bekerja efektif dan terintegrasi untuk mencapai kepuasan dengan segala daya upayanya. Motivasi kerja merupakan bagian faktor yang turut menentukan kinerja seseorang. Besar atau kecilnya motivasi berpengaruh pada kinerja seseorang dan tergantung pada seberapa banyak intensitas motivasi yang diberikan. Perbedaan motivasi kerja bagi pegawai biasanya tercermin dalam berbagai kegiatan dan prestasi yang dicapainya.

Menurut Hasibuan, (2014) motivasi adalah bagaimana caranya mengarahkan daya dan potensi bawahan, agar mau bekerja sama secara produktif berhasil dan mewujudkan tujuan yang telah ditentukan. Menurut Soeroso, (2004) motivasi merupakan suatu proses psikologis yang memperlihatkan interaksi antara sikap, kebutuhan, persepsi, dan keputusan yang terjadi pada seseorang. Dan motivasi sebagai proses psikologis timbul dari faktor dalam diri orang-orang itu sendiri yang disebut faktorintrinsik atau faktor dari luar diri yang disebut factor ekstrinsik. Menurut Faustino dalam buku (Kadarisman, 2013) mengemukakan sebagai berikut motivasi seorang pekerja untuk bekerja biasanya merupakan hal yang rumit, karena motivasi ini melibatkan faktor-faktor individual dan faktor-faktor organisasional. (Mangkunegara, 2017) menyatakan bahwa motivasi kerja dapat diukur melalui indikator sebagai berikut : 1) kerja keras, 2) orientasi masa depan, 3) tingkat cita-cita yang tinggi, 4) orientasi tugas/sasaran, 5) usaha untuk maju, 6) ketekunan, 7) rekan kerja, 8) pemanfaatan waktu.

\section{Pengawasan}

Pengawasan merupakan bagian dari fungsi manajemen sebagai suatu kesatuan yang utuh dan tidak dapat dipisah-pisahkan dari kegiatan organisasi. Menurut Manullang, (2012) pengawasan merupakan suatu proses untuk menetapkan pekerjaan apa yang sudah dilaksanakan, menilainya dan mengoreksi bila perlu dengan maksud supaya pelaksanaan pekerjaan sesuai dengan rencana semula. Pengawasan adalah segenap kegiatan untuk meyakinkan dan menjamin bahwa tugas atau pekerjaan telah dilakukan sesuai dengan rencana yang telah ditetapkan. Dalam hal ini pengawasan juga penting karena dapat menjadi tolak ukur dalam memberikan penilaian terhadap pekerjaan seseorang dalam sebuah organisasi. Menurut (Terry, 2012) mengatakan bahwa pengawasan adalah "suatu proses untuk menilai kesesuaian pekerjaan para anggota organisasi pada berbagai bidang dan berbagai tindakan manajemen dengan program yang telah ditetapkan sebelumnya.

Selanjutnya, berdasarkan Instruksi presiden Nomor 1 Tahun1989 tentang Pedoman Pelaksanaan Pengawasan Melekat, dikemukakan sebagai berikut : Pengawasan melekat adalah serangkaian kegiatan yang bersifat sebagai pengendalian yang terus-menerus, dilakukan oleh atasan langsung terhadap bawahannya, secara preventif atau represif agar pelaksanaan tugas bawahan tersebut berjalan secara efektif dan efisien sesuai dengan rencana kegiatan dan peraturan perundang-undangan yang berlaku. Menurut Rachman, (2001) salah satu indikator keberhasilan suatu organisasi pemerintah dalam mencapai tujuannya banyak ditentukana oleh keberhasilan pengawasan. Jika pengawasan berjalan dengan baik maka pengawasan merupakan unsur paling pokok dalam menentukan keberhasilan suatu program.

Keberhasilan program pengawasan sendiri dapat dilihat dari berbagai macam indikator sebagai berikut: 1) Indikator meningkatnya disiplin, prestasi dan pencapaian sasaran pelaksanaan tugas, antara lain: a) Rencana yang disusun dapat menggambarkan adanya sasaran yang jelas dan dapat diukur, terlihat kaitan antara rencana dengan program dan anggaran: $b$ ) Tugas dapat selesai sesuai dengan rencana, baik dilihat dari aspek fisik maupun biaya. 2) Indikator berkurangnya penyalahgunaan wewenang yaitu berkurangnya tuntutan masyarakat terhadap pemerintah. 3) Indikator berkurangnya kebocoran, pemborosan dan pungutan liar 
antara lain: a) Kualitas dan kuantitas kasus-kasus penyimpangan, penyelewengan, kebocoran, pemborosan dapat dikurangi sebagaimana laporan pengawasan fungsional dan laporan pengawasan lainnya; b) Berkurangnya tingkat kesalahan dalam pelaksanaan tugas. Menurut Kartono, (2014), indikator pengawasan adalah sebagai berikut:1) menentukan ukuran pelaksanaan, 2) memberikan penilaian, dan 3) mengadakan korektif.

\section{Budaya Organisasi}

Menurut Mas'ud, (2004), budaya organisasional adalah : sistem makna, nilai-nilai dan kepercayaan yang dianut bersama dalam suatu organisasi yang menjadi dasar untuk bertindak dan membedakan organisasi yang satu dengan organisasi yang lain, budaya organisasi selanjutnya menjadi identitas atau karakter utama organisasi yang dipelihara dan dipertahankan. Mas'ud juga mengatakan suatu budaya yang kuat merupakan perangkat yang sangat bermanfaat untuk mengarahkan perilaku, karena membantu karyawan untuk melakukan pekerjaan yang lebih baik sehingga setiap karyawan mengawali karirnya perlu memahami budaya dan bagaimana budaya tersebut terimplementasikan dalam melaksanakan pekerjaan.

Menurut (Robbins, 2003) mendefinisikan budaya organisasi (organizational culture) sebagai "nilai-nilai, prinsip-prinsip, tradisi dan cara-cara bekerja yang dianut bersama oleh para anggota organisasi dan mempengaruhi cara mereka bertindak". Dalam kebanyakan orgsanisasi, nilai-nilai dan praktik-praktik yang dianut bersama (shared) ini telah berkembang pesat seiring dengan perkembangan zaman dan benar-benar sangat mempengaruhi bagaimana sebuah organisasi dijalankan. Definisi tersebut menurut (Robbins, 2003) menggambarkan bahwa adanya budaya organisasi sesungguhnya tumbuh karena diciptakan dan dikembangkan oleh individu-individu yang bekerja dalam suatu organisasi, dan diterima sebagai nilai-nilai yang harus dipertahankan dan diteruskan kepada setiap anggota baru.

Di bawah ini merupakan karakteristik utama yang menjadi pembeda budaya organisasi menurut (Robbins \& Judge, 2011) adalah: Inisiatif individual, toleransi terhadap tindakan beresiko, arah, integrasi, dukungan dari manajemen, pengawasan, identitas, sistem penghargaan, toleransi terhadap konflik dan pola komunikasi. Lebih lanjut (Robbins \& Judge, 2011) menyebutkan ada 7 (tujuh) karakteristik budaya organisasi sebagai berikut: inovasi dan keberanian mengambil resiko (inovation and risk taking), perhatian terhadap detil (attention to detail), berorientasi kepada hasil (outcome orientation), berorientasi kepada manusia (people orientation), berorientasi tim (team orientation), agresifitas (aggressiveness), stabilitas (stability)

\section{Remunerasi}

Kata remunerasi menurut Oxford American Dictionary, Remuneration adalah Payment atau Reward yang berarti pembayaran, penghargaan, imbalan yang mana istilah imbalan sering juga dalam Bahasa Indonesia digunakan istilah kompensasi. Berbagai buku-buku Management sumber daya Marusia yang banyak beredar di Indonesia terutama buku yang merupakan terjemahan yang berasal dari Amerika menggunakan istilah kompensasi untuk mengungkapkan istilah remunerasi, namun bahasa Inggris maupun organisasi Buruh Internasional (International Labour Organization/ILO) menyebutnya dengan istilah Remuneration. Menurut Edwin Flippo dalam (Hasibuan, 2014), upah didefinisikan sebagai balas jasa yang adil dan layak diberikan kepada para pekerja atas jasa-jasanya dalam mencapai tujuan organisasi). Demikian juga menurut Andrew "A remuneration is a reward payment or reimbursement for services rendered" (Remunerasi adalah suatu hadiah, pembayaran, atau balas jasa untuk jasa yang diberikan). 
Istilah remunerasi seringkali disama artikan dengan istilah kompensasi. Ada beberapa ahli yang menyatakan bahwa istilah remunerasi dan kompensasi adalah sama. Pembedanya hanya pada penempatan kedua kata tersebut. Istilah remunerasi ini memang jarang sekali dibahas. Program remunerasi, merupakan salah satu program reformasi birokrasi yang telah dicanangkan pemerintah melalui pemberian tunjangan tambahan yang diberikan oleh lembaga sesuai dengan kinerja yang telah dilakukan oleh masing masing pelaku kerja sebagai imbalan atau jasa atas kinerja yang dihasilkan. Paling tidak ada 12 lembaga pemerintahan yang sedang mengalami reformasi birokrasi salah satu diantaranya Departemen Keuangan.

Menurut (Hariandja, 2002), remunerasi adalah imbalan kerja yang dapat berupa gaji, honorarium, tunjangan tetap, insentif, bonus atas prestasi, pesangon, atau pensiun. Sedangkan pengertian remunerasi menurut kamus besar bahasa Indonesia adalah "Pemberian hadiah, jasa atau imbalan. Bagi Pegawai Negeri Sipil, remunerasi berarti imbalan kerja di luar gaji yang dikaitkan dengan system penilaian kinerja. Remunerasi yang ada ditubuh Kementerian

\section{METODE PENELITIAN}

Jenis penelitian yang digunakan adalah penelitian survei, yaitu penelitian yang mengambil sampel dari suatu populasi dan menggunakan kuisioner sebagai alat pengumpulan data. Pendekatan yang digunakan adalah deskripsi kuantitatif ( penelitian yang menggunakan angka, mulai dari pengumpulan data, penafsiran terhadap data, serta penampilan hasilnya ).dan merupakan penelitian terhadap masalah-masalah yang diteliti, berupa fakta-fakta saat ini dari suatu populasi. Tujuannya adalah untuk menguji hipotesis atau menjawab pertanyaan yang berkaitan dengan current status dari subjek yang diteliti. Populasi pada penelitian ini adalah seluruh pegawai yang bekerja pada satuan kerja Biro Sumber Daya Manusia Polda Sumatera Utara, yang berjumlah 86 orang. Adapun sebaran populasi penelitian ini tersebar berdasarkan bidang pekerjaan. Dalam penelitian ini seluruh populasi pegawai yang bekerja pada satuan kerja Biro Sumber Daya Manusia Polda Sumut sebanyak 86 pegawai dengan mengambil sebanyak 40 Pegawai Negeri Sipil sebagai sampel. Penelitian ini menggunakan Purposive Sampling / Judgement Sampling, dimana sampel dipilih dari suatu populasi berdasarkan pertimbangan ahli maupun pertimbangan ilmiah. Teknik ini memberikan syarat yang cukup ketat agar sampel yang dipilih sesuai dengan karakteristik yang dikehendaki dalam analisis. Sebelum melakukan pengujian hipotesis dari penelitian ini, terlebih dahulu dilakukan pengujian asumsi klasik untuk memastikan bahwa alat uji regresi berganda dapat digunakan atau tidak dalam penelitian. Apabila uji asumsi klasik telah terpenuhi, maka alat uji statistik regreai linier berganda dapat pergunakan. Analisis data menggunakan analisis regresi linier berganda.

\section{HASIL DAN PEMBAHASAN}

\section{Uji Asumsi Klasik}

Sebelum melakukan pengujian hipotesis dari penelitian ini, terlebih dahulu dilakukan pengujian asumsi klasik untuk memastikan bahwa alat uji regresi berganda dapat digunakan atau tidak dalam penelitian. Apabila uji asumsi klasik telah terpenuhi, maka alat uji statistik regreai linier berganda dapat pergunakan.

\section{Uji Normalitas}

Uji normalitas dilakukan untuk mengetahui apakah dalam sebuah regresi telah berdistribusi normal atau mendekati normal. Pada gambar 1 grafik P-P Plot diatas terlihat bahwa titik-titik menyebar di sekitar garis diagonal dan penyebarannya mengikuti arah garis diagonal (Juliandi, Irfan, \& Manurung, 2014). Dari grafik ini dapat disimpulkan bahwa model garis regresi memenuhi asumsi normalitas. 


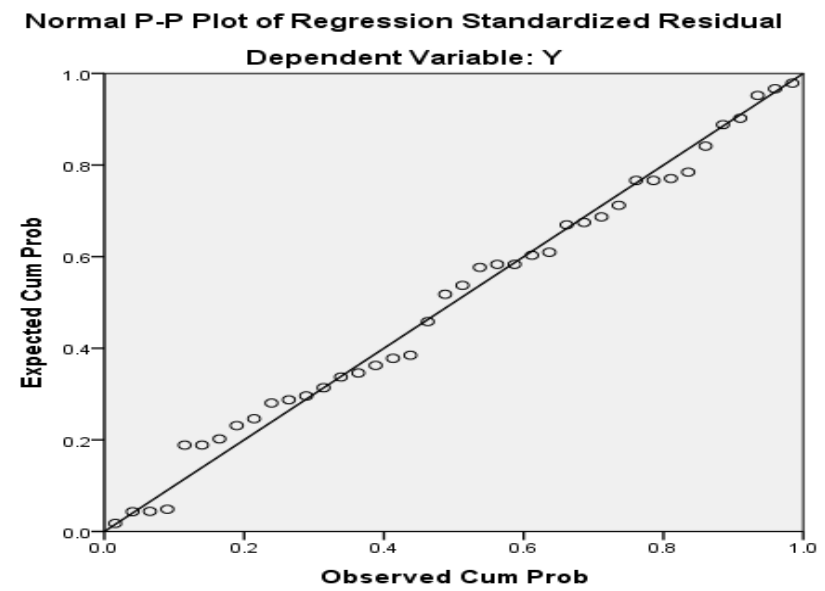

Gambar 1. Uji Normal P-P PLOT

\section{Uji Multikolinieritas}

Berdasarkan Tabel 1 di bawah ini terlihat nilai VIF untuk variabel bebas yang terdiri atas pengawasan, budaya organisasi dan remunerasi lebih kecil dari 5 (VIP $<5$ ), Sedangkan nilai tolerance-nya lebih besar dari 0.10 (tolerance>0,1) (Santoso, 2012). Hal ini menunjukkan bahwa variabel bebas dalam penelitian ini tidak terdapat gejala multikolinieritas. Hasil pengujian terlihat pada Tabel 1 di bawah ini :

Tabel 1. Hasil Uji Multikolinieritas

\begin{tabular}{|c|c|c|c|c|c|c|c|c|}
\hline \multirow{2}{*}{\multicolumn{2}{|c|}{ Model }} & \multicolumn{2}{|c|}{$\begin{array}{l}\text { Unstandardized } \\
\text { Coefficients }\end{array}$} & \multirow{2}{*}{$\begin{array}{c}\text { Standardized } \\
\text { Coefficients } \\
\text { Beta }\end{array}$} & \multirow[b]{2}{*}{$\mathrm{t}$} & \multirow[b]{2}{*}{ Sig. } & \multicolumn{2}{|c|}{$\begin{array}{l}\text { Collinearity } \\
\text { Statistic }\end{array}$} \\
\hline & & $\mathrm{B}$ & Std. Error & & & & Tolerance & VIF \\
\hline \multirow[t]{4}{*}{1} & (Constant) & .420 & .503 & & .834 & .410 & & \\
\hline & Pengawasan & -.159 & .084 & -.221 & -1.893 & .066 & .686 & 1.458 \\
\hline & Budaya organisasi & .879 & .114 & .751 & 7.696 & .000 & .979 & 1.021 \\
\hline & Remunerasi & .216 & .090 & .283 & 2.409 & .021 & .674 & 1.483 \\
\hline
\end{tabular}

\section{Uji Heteroskedastisitas}

Menurut (Juliandi, Irfan, \& Manurung, 2015) suatu asumsi penting dari model linier klasik adalah bahwa gangguan yang muncul dalam fungsi regresi populasi adalah homoskedastik yaitu semua gangguan memiliki varians yang sama. Hasil pengujian terlihat pada Gambar 2 dibawah:

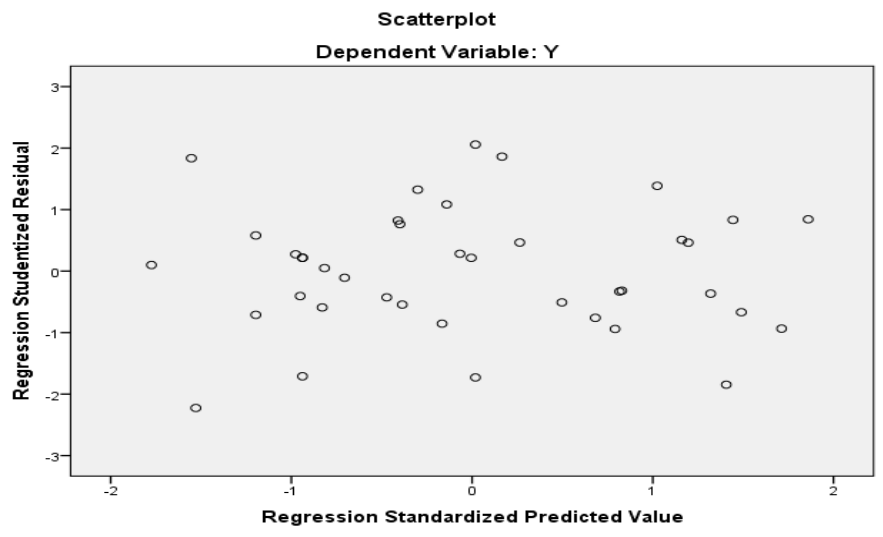

Gambar 2. Uji Heteroskedastisitas 
Berdasarkan Gambar 2 di atas dari hasil tampilan output SPSS dengan jelas menunjukkan bahwa titik-titik menyebar dibawah dan diatas angka 0 , serta tidak membentuk pola maka dapat disimpulkan bahwa pada model regresi tidak terdapat unsur heteroskedastisitas, sehingga model regresi layak dipakai untuk memprediksi model penelitian.

\section{Model Regresi Linier Berganda}

Model regresi linier berganda dilakukan untuk mengetahui besarnya pengaruh variabel bebas (Pengawasan, Budaya Organisasi dan Remunerasi) terhadap variabel terikat (Motivasi Kerja). Berdasarkan pengujian menggunakan program SPSS, maka hasil persamaan regresi linier berganda penelitian dapat dilihat pada Tabel 2 yaitu :

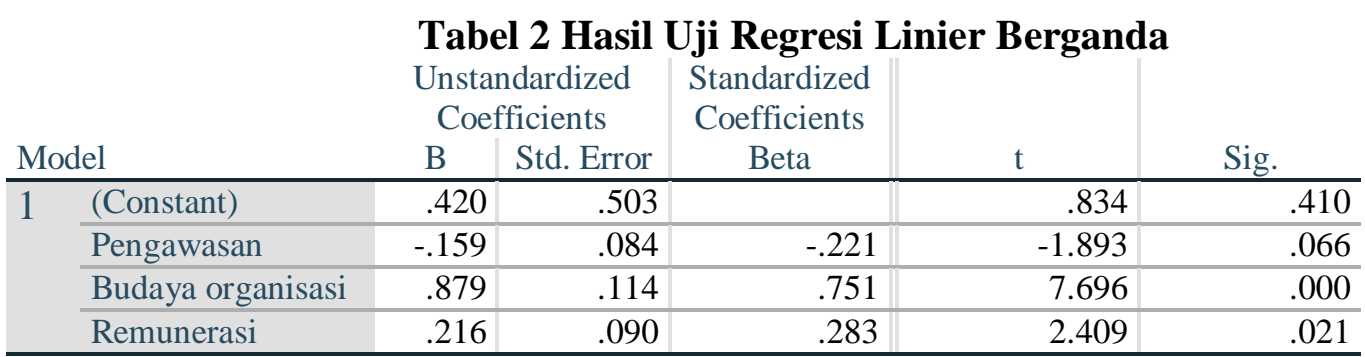
adalah :

Berdasarkan Tabel 4.11, model persamaan regresi linier berganda dalam persamaan ini

$$
Y=0.420-0.159 X_{1}+0.879 X_{2}+0.216 X_{3}+\varepsilon
$$

Berdasarkan persamaan tersebut dapat diuraikan sebagai berikut :

a. Konstanta bernilai 0.420 menunjukkan bahwa jika tidak ada pengaruh dari variabel pengawasan, budaya organisasi dan remunerasi ( $\mathrm{X}_{1}, \mathrm{X}_{2}, \mathrm{X}_{3}$ ) maka motivasi kerja (Y) akan tetap ada sebesar 0.420 satuan.

b. Koefisien pengawasan $\left(\beta_{1}\right)=-0.159$, ini menunjukkan setiap terjadi kenaikan variabel pengawasan sebesar $100 \%$, maka akan menurunkan motivasi kerja sebesar -0.159 satuan.

c. Koefisien budaya organisasi $\left(\beta_{2}\right)=0.879$, ini menunjukkan setiap terjadi peningkatan variabel budaya organisasi sebesar $100 \%$, maka akan meningkatkan motivasi kerja sebesar 0.879 satuan.

d. Koefisien remunerasi $\left(\beta_{3}\right)=0.216$, ini menunjukkan setiap terjadi peningkatan variabel remunerasi sebesar $100 \%$, maka akan meningkatkan motivasi kerja sebesar 0.216 satuan.

\section{Uji Hipotesis}

\section{Uji F ( Uji Serempak )}

Uji $\mathrm{F}$ dilakukan untuk melihat secara bersama-sama pengaruh dari variabel $\mathrm{X}_{1}, \mathrm{X}_{2}$, dan $\mathrm{X}_{3}$ berupa pengawasan, budaya organisasi dan remunerasi terhadap motivasi kerja pegawai pada Satuan kerja Biro Sumber Daya Manusia Polda Sumut.

\section{Tabel 3. Hasil Uji F}

\begin{tabular}{l|c|r|r|r|c} 
Model & $\begin{array}{c}\text { Sum of } \\
\text { Squares }\end{array}$ & df & Mean Square & F & \multicolumn{1}{c|}{ Sig. } \\
\hline 1 Regression & 2.869 & 3 & .956 & 23.758 & $.000^{\mathrm{b}}$ \\
\hline Residual & 1.449 & 36 & .040 & & \\
\hline Total & 4.319 & 39 & & & \\
\hline
\end{tabular}

Berdasarkan hasil perhitungan didapatkan nilai $F_{\text {hitung }}$ sebesar 23.758 dengan tingkat signifikan (Sig.) sebesar $0.000^{\mathrm{b}}$. Jadi $\mathrm{F}_{\text {hitung }}>\mathrm{F}_{\text {tabel }}(23.758>2.85)$ pada signifikansi (Sig.) $<5 \%$ $(0.000<0.05)$, artinya pengawasan, budaya organisasi dan remunerasi secara bersama-sama berpengaruh positif dan signifikan terhadap motivasi kerja pegawai pada Satuan kerja Biro Sumber Daya Manusia Polda Sumut. Maka, dapat disimpulkan Ho ditolak. Dengan demikian 
terdapat pengaruh signifikan secara bersama-sama pengawasan, budaya organisasi dan remunerasi terhadap motivasi kerja pegawai pada Satuan kerja Biro Sumber Daya Manusia Polda Sumut.

\section{Uji t ( Uji Parsial )}

Uji t ( Uji parsial) dilakukan untuk melihat secara individu pengaruh dari variabel bebas $\left(\mathrm{X}_{1}, \mathrm{X}_{2}\right.$ dan $\left.\mathrm{X}_{3}\right)$ berupa pengawasan, budaya organisasi dan remunerasi secara parsial berpengaruh positif dan signifikan terhadap motivasi kerja pegawai pada satuan kerja Biro Sumber Daya Manusia Polda Sumut. Maka : derajat bebas $=n-k=40-3=37$. Uji thitung yang dilakukan adalah uji dua arah, maka $t_{\text {tabel }}$ yang digunakan $1 / 2$ atau $t(0.05: 37)$ sehingga didapat nilai $t_{\text {tabel }}=2.026$. Berdasarkan pengujian, maka hasil uji t penelitian terlihat pada Tabel 4 yaitu

\begin{tabular}{|c|c|c|c|c|c|c|}
\hline & & Tabel 4. & Uji T (Uji & Parsial) & & \\
\hline & & $\begin{array}{l}\text { Unstanc } \\
\text { Coeff }\end{array}$ & $\begin{array}{l}\text { ardized } \\
\text { cients }\end{array}$ & $\begin{array}{l}\text { Standardized } \\
\text { Coefficients }\end{array}$ & & \\
\hline & & B & Std. Error & Beta & $\mathrm{t}$ & Sig. \\
\hline 1 & (Constant) & .420 & .503 & & .834 & .410 \\
\hline & Pengawasan & -.159 & .084 & -.221 & -1.893 & .066 \\
\hline & $\begin{array}{l}\text { Budaya } \\
\text { organisasi }\end{array}$ & .879 & .114 & .751 & 7.696 & .000 \\
\hline & Remunerasi & .216 & .090 & .283 & 2.409 & .021 \\
\hline
\end{tabular}

Berdasarkan Tabel 4 dapat dilihat bahwa :

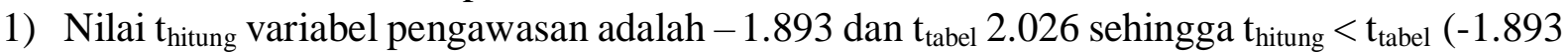
$<2.026$ ), dan signifikan $0.066>0.05)$ artinya Ho diterima. Sehingga dapat disimpulkan bahwa pengawasan berpengaruh negatif dan tidak signifikan terhadap motivasi kerja pegawai pada satuan kerja Biro Sumber Daya Manusia Polda Sumut.

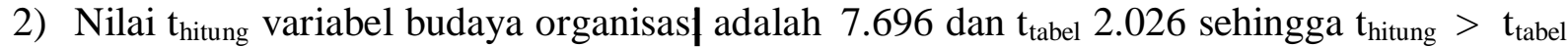
$(7.696>2.026)$, dan signifikan (Sig.) $<5 \%$ ( $0.000<0.05)$ artinya Ho ditolak. Sehingga dapat disimpulkan bahwa budaya organisasi berpengaruh signifikan dan positif terhadap motivasi kerja pegawai pada satuan kerja Biro Sumber Daya Manusia Polda Sumut.

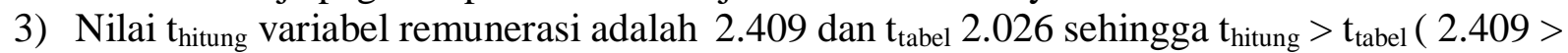
2.026 ), dan signifikan (Sig.) $<5 \%(0.021<0.05)$ artinya Ho ditolak. Sehingga dapat disimpulkan bahwa remunerasi berpengaruh signifikan dan positif terhadap motivasi kerja pegawai pada satuan kerja Biro Sumber Daya Manusia Polda Sumut.

\section{Koefisien Determinasi ( $\mathbf{R}^{2}$ )}

Pengujian koefisien determinasi digunakan untuk mengukur seberapa besar kontsribusi variabel bebas terhadap variabel terikat. Koefisien determinasi berkisar antara nol sampai dengan satu $\left(0<R^{2}<1\right)$. Jika $R^{2}$ semakin besar (mendekati satu), maka pengaruh variabel bebas adalah erat terhadap variabel terikat $(\mathrm{Y})$, hasil pengujian koefisien determinasi terlihat pada tabel 5 yaitu :

Tabel 5. Koefisien Hasil Determinasi

\begin{tabular}{cc|c|c|c|c} 
Model & $\mathrm{R}$ & R Square & $\begin{array}{c}\text { Adjusted R } \\
\text { Square }\end{array}$ & $\begin{array}{c}\text { Std. Error of } \\
\text { the Estimate }\end{array}$ & Durbin-Watson \\
\hline 1 & $.815^{\mathrm{a}}$ & .664 & .636 & .20065 & 1.648 \\
\hline
\end{tabular}

a. Predictors: (Constant), X3, X2, X1

b. Dependent Variable: $Y$ 
Pada tabel diatas, dapat dilihat hasil analisis regresi secara keseluruhan menunjukkan nilai Adjusted $R$ Square $\left(\mathrm{R}^{2}\right)$ sebesar 0,636 menunjukkan bahwa korelasi atau hubungan motivasi kerja (variabel dependen) dengan pengawasan, budaya organisasi dan remunerasi (variabel independen) mempunyai tingkat hubungan yang kuat. Angka ini mengidentifikasikan bahwa motivasi kerja (variabel dependen) dengan pengawasan, budaya organisasi dan remunerasi (variabel independen) sebesar 63,6\%, sedangkan selebihnya sebesar 36,4\% dijelaskan oleh sebab-sebab lain yang tidak diteliti dalam penelitian ini.

\section{Pembahasan}

\section{Pengaruh Pengawasan terhadap Motivasi Kerja}

Hasil analisis data statistik membuktikan bahwa pengawasan berpengaruh negatif dan tidak signifikan terhadap motivasi kerja pegawai pada satker Biro Sumber Daya Manusia Polda Sumut. Ini berarti bahwa pengawasan yang dilakukan pimpinan kurang meningkatkan motivasi kerja pegawai pada satker Biro Sumber Daya Manusia Polda Sumut. Berdasarkan tabel frekuensi jawaban responden variabel pengawasan dominan menunjukkan jawaban kurang setuju dan tidak setuju. Selanjutnya bila dikaitkan dengan fenomena yang terjadi di satker Biro Sumber Daya Manusia Polda Sumut terdapat kesesuaian dengan hasil penelitian. Hasil penelitian ini tidak mendukung teori sebelumnya yang dikemukakan oleh (Manullang, 2012) pengawasan dilakukan untuk meningkatkan kuantitas dan kualitas dalam meningkatkan motivasi kerja, karena pengawasan dalam penelitian ini berpengaruh negatif dan tidak signifikan terhadap motivasi kerja pegawai. Hal ini dapat diartikan bahwa penilaian pengawasan yang dilakukan di Polda Sumatera Utara oleh atasan kepada pegawai pada Biro Sumber Daya Manusia dilakukan secara rutin dan tepat waktu yaitu dilakukan satu kali dalam setahun. Hal ini tentu membuat pegawai menjadi cenderung lebih bersemangat untuk menyelesaikan pekerjaan. Disisi lain, penilaian yang dilakukan oleh atasan sering kali bias. Hal ini terjadi karena sering adanya mutasi jabatan. Pekerjaan yang dilakukan juga sering kali lebih dari jenis pekerjaan yang diberikan sehingga setiap pegawai dituntut untuk lebih professional, cepat, tepat dan tuntas. Sehingga bentuk penilaian sebagai indikator pengawasan dapat menurunkan motivasi kerja pegawai pada Biro Sumber Daya Manusia Polda Sumut. Seringnya mutasi jabatan pimpinan dan pekerjaan yang beragam menuntut dapat menurunkan kepuasan kerja dan menurunkan motivasi kerja pada jabatan disuatu instansi.

Hal ini disebabkan karena pengawasan yang dilakukan pimpinan merupakan pengawasan melekat dan tetap diberlakukan, sehingga dalam pelaksanaan pekerjaan pegawai pada satker Biro Sumber Daya Manusia Polda Sumut tetap berjalan, sesuai dengan ketentuan yang berlaku dengan ada atau tidak adanya pimpinan melakukan pengawasan secara langsung, seperti pelaksanaan apel pagi telah ditentukan pukul 07.30 dan pulang kantor pukul 15.30 bahkan masih ada pegawai yang menyelesaikan pekerjaannya melebihi jam pulang kantor. Namun demikian ada juga pegawai yang datang terlambat ke kantor, pulang kantor sebelum waktunya dan menyelesaikan pekerjaaan tidak tapat pada waktunya serta tidak sungguh-sungguh melaksanakan pekerjaannya, sehingga jawaban responden dalam penelitian ini yang secara umum untuk pernyataan pengawasan dominan kurang setuju dan tidak setuju mendukung keadaan pegawai pada satuan kerja Biro SDM Polda Sumut, dimana pengawasan kurang berpengaruh dalam meningkatkan motivasi kerja pegawai. Walaupun pengawasan tetap perlu dilakukan pimpinan minimal untuk menghindari terjadinya pelanggaran dalam melaksanakan pekerjaan. Hasil penelitian sejalan dengan hasil penelitian yang dilakukan oleh (Marpaung, 2017) dan (Akila, 2015) menunjukkan bahwa pengawasan berpengaruh signifikan terhadap motivasi kerja. 


\section{Pengaruh Budaya Organisasi terhadap Motivasi Kerja}

Hasil analisis data statistik membuktikan bahwa terdapat pengaruh signifikan dan positif antara budaya organisai terhadap motivasi kerja pegawai pada satker Biro Sumber Daya Manusia Polda Sumut, yang mengacu kepada suatu sistem makna bersama yang dianut oleh pegawai dan membedakannya dengan organisasi lain. Hal ini berarti bahwa semakin kuat budaya organisasi yang dianut, maka akan semakin meningkatkan motivasi kerja pegawai pada satker Biro Sumber Daya Manusia Polda Sumut. Berdasarkan hasil penelitian didapatkan bahwa mayoritas responden menyatakan setuju pada variabel budaya organisasi sebanyak 83.93\%. Hal tersebut dapat diartikan bahwa pegawai pada satuan kerja Biro SDM Polda Sumut mempunyai kreativitas dalam melaksanakan pekerjaan. Pekerjaan yang dilakukan dalam satuan kerja Biro SDM sangat bervariasi dan menuntut banyak ide dan inisiatif baru karena berbagai permasalahan yang dihadapi cenderung kompleks. Kreativitas pada pegawai di satuan kerja Biro SDM Polda Sumut mempengaruhi dan bersifat positif meningkatkan kebanggaan dan semangat dalam melaksanakan pekerjaan kaitannya dengan motivasi kerja. Penjelasan responden untuk variabel budaya organisasi dapat diketahui bahwa adanya kerja sama yang baik dalam melaksanakan pekerjaan, kepercayaan pimpinan terhadap pegawai dalam menyelesaikan pekerjaan, merasakan kesejahteraan, menyelesaikan pekerjaan lebih cepat dan berinovasi dalam menjalankan pekerjaan. Hal ini menunjukkan bahwa pegawai pada satker Biro Sumber Daya Manusia Polda Sumut memiliki budaya organisasi yang cukup baik. Hasil penelitian ini mendukung teori sebelumnya yang dikemukakan oleh (Siagian, 2014) menyatakan bahwa budaya organisasi mempunyai dampak positif yang sangat kuat terhadap perilaku para anggotanya termasuk kerelaan untuk meningkatkan kinerja, dengan kata lain budaya organisasi berpengaruh signifikan dan positif untuk meningkatkan motivasi kerja pegawai. Hasil penelitian sejalan dengan hasil penelitian yang dilakukan oleh (Koesmono, 2005) dan (Koesmono, 2014) yang menunjukkan bahwa budaya organisasi berpengaruh signifikan terhadap motivasi kerja.

\section{Pengaruh Remunerasi terhadap Motivasi Kerja}

Hasil analisis data statistik membuktikan bahwa terdapat pengaruh signifikan dan positif antara remunerasi terhadap motivasi kerja pegawai pada satker Biro Sumber Daya Manusia Polda Sumut. Hal ini membuktikan bahwa pemberian remunerasi yang sesuai dengan beban kerja yang diemban akan meningkatkan motivasi kerja pegawai pada satker Biro Sumber Daya Manusia Polda Sumut. Sebaliknya apabila pemberian remunerasi tidak sesuai dengan beban kerja yang diemban akan menurunkan motivasi kerja pegawai pada satker Biro Sumber Daya Manusia Polda Sumut. Berdasarkan tabel frekuensi jawaban responden variabel remunerasi menunjukkan bahwa kuesioner dominasi jawaban kurang setuju sebanyak 50,71 persen. Selanjutnya bila dikaitkan dengan fenomena yang terjadi di satker Biro Sumber Daya Manusia Polda Sumut terdapat kesesuaian dengan hasil penelitian. Permasalahan yang menyangkut remunerasi bahwa tingkat keadilan remunerasi yang selama ini diterima belum sepenuhnya sesuai dengan beban kerja pegawai pada satker Biro Sumber Daya Manusia Polda Sumut dan masih adanya kecemburuan pegawai terhadap instansi-instansi pemerintahan lainnya yang menerima remunerasi lebih besar dari instansi Polri, sedangkan dalam golongan kelas jabatan sama. Oleh karena itu, kurangnya kebangaan menjadi pegawai di Satuan kerja Biro SDM Polda Sumut dapat diindikasikan karena mendapatkan remunerasi yang belum layak dan tidak sesuai dengan beban kerja. Hal tersebut mengakibatkan menurunnya kebanggan sebagai pegawai di Satuan Kerja Polda Sumut dalam kaitannya dengan motivasi kerja. Jika remunerasi yang diterima dirasakan kurang adil, maka ada kemungkinan akan menurunkan motivasi kerja pegawai pada satker Biro Sumber Daya Manusia Polda Sumut, oleh karena itu organisasi perlu lebih mengakui dan menghormati beban kerja dan prestasi kerja pegawai serta 
mengurangi adanya ketidakadilan dari sistem remunerasi. Remunerasi dianggap sebagai gaji tambahan pegawai, dimana gaji bulanan yang biasa diterima belum mencukupi untuk membeli kebutuhan yang dapat menunjang keberhasilan pekerjaan pegawai. Hasil penelitian sejalan dengan hasil penelitian yang dilakukan oleh (Pratama \& Prasetya, 2017); (Purwanto, 2016) dan (Hartono, Sulaeman, Nopianna, \& Sari, 2019) yang menunjukkan bahwa remunerasi berpengaruh signifikan terhadap motivasi kerja.

\section{Pengaruh Pengawasan, Budaya Organisasi dan Remunerasi Terhadap Motivasi Kerja.}

Motivasi yang tinggi dapat dicapai apabila seluruh pegawai dan pimpinan dapat melakukan pengawasan yang optimal, membentuk budaya organisasi yang kuat dan pemberian remunerasi yang sesuai dengan beban kerja yang diemban. Berdasarkan pengujian hipotesis penelitian menunjukkan bahwa terdapat pengaruh positif dan signifikan secara simultan antara pengawasan, budaya organisasi dan remunerasi terhadap motivasi kerja pegawai pada satker Biro Sumber Daya Manusia Polda Sumut. Dimana yang artinya dengan pengawasan, budaya organisasi dan remunerasi yang baik akan meningkatkan motivasi kerja pegawai pada satker Biro Sumber Daya Manusia Polda Sumut.

Motivasi berhubungan dengan kekuatan (dorongan) yang ada dalam diri manusia, sehingga menunjukkan pada kondisi-kondisi yang menyebabkan adanya keragaman kualitas, arah, intensitas dan lamanya perilaku kerja. Motivasi dapat diartikan sebagai kekuatan (energi) seseorang yang dapat menimbulkan tingkat ketekunan dalam melaksanakan suatu kegiatan, baik yang bersumber dari dalam diri maupun dari luar pegawai pada satker Biro Sumber Daya Manusia Polda Sumut. Pengawasan dilaksanakan agar tahapan pekerjaan bisa berjalan sesuai rencana. Perlunya pengawasan melekat dari pimpinan karena harus disadari bahwa manusia sebagai pelaksana memiliki keterbatasan. Sehingga pengawasan juga berpengaruh terhadap motivasi kerja pegawai pada satker Biro Sumber Daya Manusia Polda Sumut.

Budaya organisasi memiliki peran penting dalam memberikan motivasi kerja pegawai pada satker Biro Sumber Daya Manusia Polda Sumut, dimana budaya organisasi biasanya dikaitkan dengan nilai, norma, sikap dan etika kerja yang dipegang pegawai. Remunerasi juga sebagai salah satu faktor mempunyai pengaruh terhadap motivasi kerja pegawai pegawai pada satker Biro Sumber Daya Manusia Polda Sumut dalam melaksankan pekerjaannya. Dari ketiga variabel bebas tersebut yaitu pengawasan, budaya organisasi dan remunerasi berpengaruh secara simultan terhadap motivasi kerja pegawai pada satker Biro Sumber Daya Manusia Polda Sumut. Namun variabel budaya organisasi memiliki pengaruh paling besar dalam meningkatkan motivasi kerja pegawai pada satker Biro Sumber Daya Manusia Polda Sumut. Selain itu pengawasan dan remunerasi juga perlu ditingkatkan untuk memberikan motivasi kerja pegawai pada satker Biro Sumber Daya Manusia Polda Sumut.

\section{KESIMPULAN}

Berdasarkan analisis hasil penelitian dan pembahasan yang telah dikemukakan sebelumnya, maka kesimpulan penelitian adalah secara parsial variabel pengawasan berpengaruh negatif dan tidak signifikan terhadap motivasi kerja pegawai pada satker Biro SDM Polda Sumatera Utara. Dengan demikian pengawasan belum mampu meningkatkan motivasi kerja pegawai pada satker Biro SDM Polda Sumatera Utara. Secara parsial variabel budaya organisasi berpengaruh secara positif dan signifikan terhadap motivasi kerja pegawai pada satker Biro SDM Polda Sumatera Utara. Dengan demikian jika budaya organisasi pada satker Biro SDM Polda Sumatera Utara semakin kuat akan meningkatkan motivasi kerja pegawai. Secara parsial variabel renumerasi berpengaruh secara positif dan signifikan terhadap motivasi kerja pegawai pada satker Biro SDM Polda Sumatera Utara. Dengan demikian jika remunerasi pada satker Biro SDM Polda Sumatera Utara ditingkatkan dan sesuai dengan beban 
kerja pegawai akan dapat meningkatkan motivasi kerja pegawai. Secara simultan variabel pengawasan, budaya organisasi dan remunerasi berpengaruh secara positif dan signifikan terhadap motivasi kerja pegawai satker Biro SDM Polda Sumatera Utara.

\section{DAFTAR PUSTAKA}

Ainanur, A., \& Tirtayasa, S. (2018). Pengaruh Budaya Organisasi, Kompetensi dan Motivasi terhadap Kinerja Karyawan. Maneggio: Jurnal Ilmiah Magister Manajemen, 1, 1-14.

Akila, A. (2015). Hubungan Pengawasan Terhadap Motivasi Kerja Karyawan pada CV. Syailendra Jaya Palembang. Jurnal Media Wahana Ekonomika, 11(4), 75-83. https://doi.org/10.31851/jmwe.v11i4.3314

Buhler, P. (2004). Alpa Teach Yourself. Management Skills dalam 24 Jam. Jakarta: Prenada Media.

Elizar, E., \& Tanjung, H. (2018). Pengaruh Pelatihan, Kompetensi, Lingkungan Kerja terhadap Kinerja Pegawai. Maneggio: Jurnal Ilmiah Magister Manajemen, 1, 46-58.

Gultom, D. K. (2014). Pengaruh Budaya Organisasi Perusahaan Dan Motivasi Terhadap Kinerja Karyawan pada PT. Perusahaan Gas Negara (Persero) Tbk Medan. Jurnal Ilmiah Manajemen Dan Bisnis, 14(2), 176-184. https://doi.org/10.30596/jimb.v14i2.194

Handoko, T. H. (2016). Manajemen (Edisi II). Yogyakarta: BPFE.

Hariandja, M. T. E. (2002). Manajemen Sumber Daya Manusia. Jakarta: Grasindo.

Hartono, B., Sulaeman, S., Nopianna, I., \& Sari, K. (2019). Pengaruh Sistem Remunerasi Terhadap Motivasi Kerja, Kepuasan Kerja dan Dampaknya Terhadap Kinerja Perawat di RS Paru Gunawan Tahun 2018. Jurnal Keperawatan Muhammadiyah, 4(2), 24-30.

Hasibuan, M. S. . (2014). Manajemen Sumber Daya Manusia. Jakarta: Bumi Aksara.

Jufrizen. (2017). Efek Moderasi Etika Kerja Pada Pengaruh Kepemimpinan Transformasional dan Budaya Organisasi Terhadap Kinerja Karyawan. E-Mabis: Jurnal Ekonomi Manajemen Dan Bisnis, 18(2), 145-158.

Jufrizen, J. (2017). Pengaruh kemampuan dan motivasi terhadap kinerja perawat Studi pada Rumah Sakit Umum Madani Medan. Jurnal Riset Sains Manajemen, 1(1), 27-34. https://doi.org/10.5281/zenodo.1036809

Jufrizen, J., Gultom, D. K., Sitorus, S. A., Sari, M., \& Nasution, M. I. (2018). The Effect of Organizational Culture and Islamic Work Ethic on Permanent Lecturers' Job Satisfaction, Organizational Commitment And Work Performance at Private Islamic Universities in the City of Medan. In Proceeding 1st International Conference of Economic Studies (ICOES) 2018 (pp. 179-186).

Jufrizen, J., Lumbanraja, P., Salim, S. R. A., \& Gultom, P. (2017). The Effect of Compensation, Organizational Culture and Islamic Work Ethic Towards the Job Satisfaction and the Impact on the Permanent Lecturers. International Business Management, 11(1), 53-60.

Jufrizen, J. (2016). Pengaruh Pengawasan Terhadap Kinerja Karyawan Melalui Disiplin Kerja Pada PT. Socfin Indonesia Medan. Jurnal Ilmiah Manajemen Dan Bisnis, 17(2), 181-195.

Jufrizen, J., \& Pulungan, D. R. (2017). Implementation of Incentive and Career Development of Performance with Motivation as an Intervening Variable. In Proceedings of AICS-Social Sciences (pp. 441-446).

Juliandi, A., Irfan, \& Manurung, S. (2014). Metode Penelitian Bisnis. Medan: UMSU Press.

Juliandi, A., Irfan, \& Manurung, S. (2015). Metodologi Penelitian Bisnis Konsep dan Aplikasi. Medan: UMSU Press.

Kadarisman, M. (2013). Manajemen Pengembangan Sumber Daya Manusia. Jakarta: PT Raja Grafindo Persada.

Kartono, K. (2014). Pemimpin dan Kepemimpinan. Jakarta: PT Raja Grafindo Persada. 
Koesmono, H. T. (2005). Pengaruh Budaya Organisasi Terhadap Motivasi Dan Kepuasan Kerja Serta Kinerja Karyawan Pada Sub Sektor Industri Pengolahan Kayu Skala Menengah Di Jawa Timur. Jurnal Manajemen \& Kewirausahaan, 7(2), 162-179. https://doi.org/10.9744/jmk.7.2.pp.\%20171-188

Koesmono, H. T. (2014). The Influence of Organizational Culture, Servant Leadership, and Job Satisfaction Toward Organizational Commitment and Job Performance Through Work Motivation as Moderating Variables for Lecturers in Economics and Management of Private Universities in Eas. Educational Research International, 3(4), 25-39.

Mangkunegara, A. A. P. (2017). Manajemen Sumber Daya Manusia (Bandung). Remaja Rosdakarya.

Manullang, M. (2012). Dasar-Dasar Manajemen. Yogyakarta: Gadjah Mada University Press. Marpaung, I. S. (2017). Pengaruh Pengawasan Terhadap Motivasi Kerja Pegawai (Studi Kasus Sekretariat DPRD Kabupaten Tapanuli Selatan). Jurnal LPPM Universitas Graha Nusantara Padangsidimpuan, 8(2), 17-25.

Martoyo, S. (2000). Manajemen Sumber Daya Manusia. Yogyakarta: BPFE.

Maryesa, L., Sukmawati, A., \& Wijayanto, H. (2016). Analisis Peran Remunerasi dan Budaya Organisasi Terhadap Kompetensi Pegawai Guna Meningkatkan Kinerja Pegawai di Lembaga Penerbangan dan Antariksa Nasional. Manajemen IKM, 11(2), 159-172.

Mas'ud, F. (2004). Survai Diagnosis Organisasional (Konsep dan Aplikasi). Semarang: BPUniversitas Diponegoro.

Mujiatun, S., Jufrizen, J., \& Ritonga, P. (2019). Model Kelelahan Emosional: Antaseden Dan Dampaknya Terhadap Kepuasan Kerja Dan Komitmen Organisasi Dosen. MIX: Jurnal Ilmiah Manajemen, 9(3), 447-465.

Muis, M. R., Jufrizen, J., \& Fahmi, M. (2018). Pengaruh Budaya Organisasi Dan Komitmen Organisasi Terhadap Kinerja Karyawan. Jesya (Jurnal Ekonomi \& Ekonomi Syariah), $1(1), 9-25$.

Nawawi, H. (2011). Manajemen Sumber Daya Manusia: Untuk Bisnis Yang Kompetitif. Yogyakarta: UGM Press.

Pratama, W. A., \& Prasetya, A. (2017). Pengaruh Sistem Remunerasi Terhadap Kepuasan Kerja Dan Motivasi Kerja Pada Perguruan Tinggi. Jurnal Administrasi Bisnis (JAB), 46(1), 52-60.

Purwanto, B. (2016). Pengaruh Remunerasi, Budaya Organisasi Dan Kepemimpinan Terhadap Motivasi Kerja Pegawai (Studi Pada Kantor Pelayanan Kekayaan Negara Dan Lelang Tangerang). Journal Badan Pengelola Jurnal Ilmiah Universitas Esa Unggul, 5(1).

Rachman, A. A. (2001). Administrasi Pemerintahan Dalam Pembangunan. Jakarta: CV Haji Mas Agung.

Riani, A. L. (2011). Budaya Organisasi. Yogyakarta: Graha Ilmu.

Robbins, S. P. (2003). Organizational Behavior. New Jersey: Prentice Hall.

Robbins, S. P., \& Judge, T. A. (2011). Organizational Behavior (14th ed.). New Jersey: Prentice Hall.

Santoso, S. (2012). Analisis SEM Menggunakan AMOS. Jakarta: PT Elek Media Komputindo. Sarwoto, S. (2011). Dasar-Dasar Organisasi Manajemen. Jakarta: Ghalia Indonesia.

Siagian, S. P. (2014). Manajemen Sumber Daya Manusia. Jakarta: Bumi Aksara.

Soeroso, S. (2004). Manajemen Sumber Daya Manusiadi Rumah Sakit; Suatu Pendekatan Sistem. Jakarta: Penerbit Buku Kedokteran EGC.

Terry, G. R. (2012). Prinsip-prinsip Manajemen. Jakarta: Bumi Aksara.

Utomo, U. (2008). Manajemen Sumber Daya Manusia. Bandung: Penerbit Arcan. 